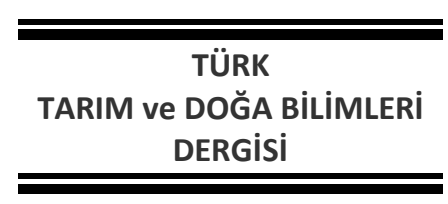

\section{Araştırma Makalesi}

www.dergipark.gov.tr/turkjans
TURKISH

JOURNAL Of AGRICULTURAL

and NATURAL SCIENCES

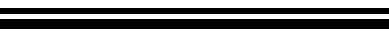

\title{
Karasu Nehri'nden (Erzincan) Alınan Su, Sediment ve Capoeta umbla Dokularındaki Ağır Metal Düzeylerinin Belirlenmesi
}

\author{
Teoman Özgür SÖKMEN ${ }^{1, *}$, Muharrem GÜNEŞ ${ }^{1}$, Muammer $\mathrm{KIRICl}^{2}$
}

${ }^{1}$ Erzican Binali Yıldırım Üniversitesi, Tercan Meslek Yüksekokulu,Mülkiyet Koruma ve Güvenlik Bölümü, Erzincan ${ }^{2}$ Bingöl Üniversitesi, Teknik Bilimler Meslek Yüksekokulu, Veterinerlik Bölümü, Bingöl.

*Sorumlu yazar: ozgursokmen@hotmail.com

Geliş Tarihi: 31.07.2018

Düzeltme Geliş Tarihi: 19.09.2018

Kabul Tarihi: 19.09.2018

\section{Özet}

Bu çalışmada, Karasu Nehri'den alınan su ve sediment örneklerinde, ayrıca nehirden yakalanan Capoeta umbla balıklarının karaciğer, solungaç ve kas dokularında bazı ağır metallerin (Alüminyum (Al), Arsenik (As), Krom $(\mathrm{Cr})$, Bakır ( $\mathrm{Cu})$, Demir (Fe), Manganez $(\mathrm{Mn})$, Nikel (Ni), Kurşun (Pb) ve Çinko $(\mathrm{Zn}))$ birikim düzeylerinin belirlenmesi amaçlanmıştır. Bu amaçla suyun sıcaklık, pH ve çözünmüş oksijen değerleri ölçülmüştür. Suda yapılan analizler sonucunda en fazla As ölçülürken, Al, Fe, Pb ve Zn metalleri suda tespit edilememiştir. Bununla beraber suda tespit edilen ağır metaller ile suda ölçülen sıcaklık, pH ve çözünmüş oksijen değerleri arasındaki ilişki karşılaştırılmıştır. Sedimentte yapılan analizler sonucunda en yüksek birikim Fe metalinde ölçülmüşken, Al, $\mathrm{Cu}$ ve $\mathrm{Mn}$ metalleri ise tespit edilememiştir. Balık dokularında ise tüm metallerin birikimi tespit edilmiştir. Metallerin genel olarak karaciğer dokusunda diğer dokulara göre daha fazla birikim gösterdiği belirlenmiştir. Tüm dokularda en fazla birikim Fe metalinde ölçülmüşken, yine tüm dokularda en düşük birikim Pb metalinde görülmüştür. Ayrıca, balıklarda tespit edilen metal seviyeleri ile balıkların ağırlık ve boyları arasındaki ilişki incelenmiştir. Suda, sedimentte ve balık dokularında belirlenen ağır metallerin miktarının ulusal ve uluslararası kurumların belirlediği kabul edilebilir değerlerle kıyaslanmış ve insanların veya sucul organizmaların sağlığına zararlı olup olmadıkları değerlendirilmiştir.

Anahtar Kelimeler: Karasu Nehri, metal birikimi, su kirliliği, Capoeta umbla, sediment.

\section{Determination of Heavy Metal Levels in Water, Sediment and Capoeta umbla Tissues of Karasu River (Erzincan)}

\begin{abstract}
In this study, it was aimed to determine the accumulation levels of some metals (Aluminum (Al), Arsenic (As), Chromium ( $\mathrm{Cr})$, Copper ( $\mathrm{Cu})$, Ferrois (Fe), Manganese ( $\mathrm{Mn})$, Nickel (Ni), Lead (Pb) and Zinc ( $\mathrm{Zn})$ ) in the muscle, liver and gill tissues of the Capoeta umbla fishes caught in the water, sediment and riverbed of Karasu River. For this purpose, water temperature, $\mathrm{pH}$ and dissolved oxygen values were measured. As a result of water analysis, the maximum amount of As was measured, but $\mathrm{Al}, \mathrm{Fe}, \mathrm{Pb}$ and $\mathrm{Zn}$ metals could not be detected in water. However, the relationship between the metals detected in water and the measured temperature, $\mathrm{pH}$ and dissolved oxygen values in water were compared. As a result of the sediment analysis, the highest accumulation was measured in Fe metal, whereas $\mathrm{Al}, \mathrm{Cu}$ and $\mathrm{Mn}$ metals were not detected. In fish tissues, accumulation of all metals was detected. It has been determined that metals generally accumulate more in the liver tissue than other tissues. While the maximum accumulation in all tissues was measured in Fe metal, the lowest accumulation in all tissues was seen in $\mathrm{Pb}$ metal. In addition, the relationship between the metal levels detected in fish and the weight and length of fish was investigated. The quantities of metals identified in water, sediment and fish tissues have been compared with acceptable values determined by national and international agencies and assessed whether they are detrimental to the health of humans or aquatic organisms.
\end{abstract}


Keywords: Karasu River, metal accumulation, water pollution, Capoeta umbla, sediment.

\section{Giriş}

Günümüzde ekosistemde yaşayan tüm canlılar için en önemli tehlikelerden biri çevre kirliliğidir. Çevre kirliliği, özellikle insanların kentsel yaşamın başlamasıyla beraber ortaya çıkmış ve sanayi devriminin gerçekleşmesine paralel olarak artmıştır (Yarsan ve ark., 2000). Özellikle yaşadığımız yüzyılda, insanoğlunun endüstriyel, tarımsal ve sosyal faaliyetleri çevrenin kirlenmesine ve ekosistemin dengesinin bozulmasına neden olmaktadır. Bunun sonucunda, tüm dünyada olduğu gibi ülkemizde de bu kirlenmeden en fazla sucul ekosistem etkilenmektedir. İçilebilir sulara sahip göl ve akarsular azalmaya başlamış; sulak alanların birçoğu kirlilik nedeniyle tahrip olmuştur (Kazancı ve Oğuzku, 2003).

Özellikle günümüzde çevre kirliliğinin en önemli nedenlerinden biri ağır metallerdir. Sucul ekosistemde yoğun olarak bulunan metaller, birçok farklı madde içeriğinde yer alması nedeniyle geniş çapta kirliliğe sebep olmaktadır. Doğada kalma süresinin çok uzun olması ve besin zinciri yoluyla canlı vücuduna kolayca girmesi sonucunda vücutta yoğun şekilde birikip olumsuz etkilere neden olabilmektedirler (Özan, 2016).

Bazı metallerin düşük konsantrasyonları canlı vücudu için gerekli iken, bazı metallerin çok düşük konsantrasyonları bile sucul ekosistemde toksik etkiye sahip olabilmektedir. Eser miktarda bile canlı da toksik etki yapabilen bu metallere ağır metaller denir. Ağır metallerin, toksik etkileri olduğu gibi, canlı dokularında özellikle spesifik dokularda birikme eğilimi de söz konusudur. Bundan dolayı, ağır metaller önemli bir kirletici grubu oluştururlar. Suda çözünürlükleri oldukça düşük olan bu maddeler, genellikle doğada oksit, sülfür, silikat ve karbonat mineralleri şeklinde bulunurlar. (Mutluay ve Demirak, 1996).

Ağır metaller, sucul ekosisteme özellikle doğal kaynaklar ve insanların faaliyetleriyle dahil olmaktadırlar (Göksu, 2003). Metaller erozyonla, rüzgarla, volkanik aktivitelerle ve atmosfer yoluyla önemli ölçüde sucul ortama karışır (Egemen, 1999). Bunların yanı sıra fosil yakıtların yanması, madenlerin çıkarılması ve işlenmesi, jeolojik ayrışma ve aşınma, tarımsal aktiviteler, evsel atıklar, endüstriyel atıklar nedeniyle de sulardaki metal konsantrasyonu artış gösterir (Şengül ve Müezzinoğlu, 1993; Sawyer ve ark., 1994). Ev ve şehir atıkları sahil sularına karışan ağır metallerin önemli kaynaklarındandır. Metabolik atıklar, deterjan gibi temizlik maddelerinin içerdiği bazı ağır metaller ve su borularının korozyonu sonucu oluşan $\mathrm{Cu}, \mathrm{Pb}, \mathrm{Zn}$ ve $\mathrm{Cd}$ gibi metaller bu tip atıkları oluşturur (Bryan, 1976).
Ağır metallerin sedimentteki birikimi, kayaçların çözünmesi, erozyon, inorganik partiküllerin ve ölü organizmaların dibe çökmesiyle meydana gelmektedir. Suda asılı partiküllere hızlıca tutunan ağır metaller zamanla çökerek sedimentte birikirler. Sedimentte biriken metaller biyojeokimyasal döngü üzerinde etkilidirler. Sedimentin ağır metalleri bünyesinde tutabileceği bir kapasitesi vardır. Bu kapasiteye ulaşıldığında sediment tabakası, bünyesinde biriken metalleri suya bırakır. Suya bırakılan metaller önemli bir kirlilik kaynağı oluşturmaktadır (Keskin, 2012; Ercişli, 2016). Ağır metallerin sedimentte birikim konsantrasyonu, sediment parçacıklarının oranına, parçacıkların boyutuna ve organik maddelerin sedimentte bulunup bulunmamasına göre değişmektedir. Ağır metallerin önemli bir birikim yeri olan sediment, sucul ortamlarda metal kirliliğinin belirlenmesinde kullanılır (Salomans ve ark., 1987; Kır ve ark., 2007).

Metallerin balıkların bünyesinde birikmesi deri, besin, su ve solungaçlar ile gerçekleşmektedir. Ağır metallerin balıklarda en önemli birikme şekli, solungaç absorbsiyonu iken, vücut yüzeyinden bu metallerin alınması ise azdır. Balıkların bünyesinde biriken metaller vücutta kan ile doku ve organlara taşınarak zamanla toksik etkilerini arttırırlar. Bu nedenlerden dolayı canlılar ağır metal yönünden sürekli izlenmekte, ekolojik sisteme ve insanlara doğrudan veya dolaylı etkileri araştırılmaktadır. Son yıllarda ülkemizde de ağır metal çalışmaları sürekli yapılmaktadır (Uslu, 2007; İsanç, 2010).

Bu çalışmada, (1) Karasu Nehri'nin suyunun $\mathrm{pH}$, sıcaklık ve çözünmüş oksijen değerleriyle ağır metal konsantrasyonları arasındaki ilişkinin belirlenmesi, (2) sediment, su ve nehirden yakalanan bölge halkı tarafından severek tüketilen önemli bir ekonomik değeri olan Capoeta umbla balıklarının kas, karaciğer ve solungaç dokularındaki metal birikim düzeylerinin belirlenmesi, (3) balıkların boyları ve ağırlıkları ile dokularda biriken ağır metal miktarları arasındaki ilişkinin belirlenmesi ve (4) su, sediment ve balık dokularında biriken ağır metal miktarlarının ulusal ve uluslararası standartlar ile karşılaştırılması amaçlanmıştır.

\section{Materyal ve Yöntem Araştırma Alanı}

Karasu Nehri, Erzurum illinde bulunan Dumlu Dağları'ndan doğar ve Fırat Nehri'nin ana koludur. Buradan Aşkale ilçesine akarak Karasu vadisi denilen bölgeden Erzincan'ın Mercan beldesine girer. Keban yakınlarında Murat Nehri ile birleşerek, Fırat Nehri'ni oluşturan akarsunun, Keban Barajı'na kadar uzunluğu 460 km'dir (Saler ve ark., 2015). 


\section{Arazi çalışmaları}

Çalışma Mart 2018 - Mayıs 2018 tarihleri arasında 3 istasyondan alınan örneklerle gerçekleştirilmiştir. Her istasyondan su ve sediment örnekleri her ay için 3'er kez ayrı ayrı alınarak 3 tekerrür olarak yapılmıştır. Balık örnekleri ise bölgede avlanan balıkçıların yardımlarıyla temin edilmiştir. Çalışma sırasında Jenco 6010 (Jenco Instruments Co. China) markalı portatif multiparametre ölçüm cihazı kullanılarak suyun sıcaklığı, pH'sı ve çözünmüş oksijen miktarı her istasyonda ölçüldü. Nehirden alınan su, sediment ve balık örnekleri propilen kaplara konarak laboratuara getirilmiştir. Su örnekleri, konsantrasyonu \%2 olacak şekilde $\mathrm{HNO}_{3}$ ile muamele edilmiştir. Analizlerin yapılacağı zamana kadar su örnekleri +4 ${ }^{\circ} \mathrm{C}$ muhafaza edilmiştir. Sediment örnekleri, ekman kepçesi yardımıyla alınarak propilen kaplar içerisinde laboratuvara getirilmiştir. Analiz işlemine başlayıncaya kadar derin dondurucuda muhafaza edilmiştir.

\section{Laboratuar çalışmaları}

Su, sediment ve balık örnekleri laboratuar çalışmaları için Erzincan Üniversitesi Temel Bilimler Uygulama ve Araştırma Merkezi Kimya Laboratuvarına getirilmiştir. Burada balıkların ağırlıkları terazi ile ve total boyları ise $\pm 1 \mathrm{~mm}$ hataya hassas ölçme tahtası ile ölçülmüştür. Ölçümlerden sonra balıkların kas, karaciğer ve solungaç dokuları alınmıştır.

Balıkların kas, solungaç ve karaciğer dokularında $\mathrm{Al}, \mathrm{Mn}, \mathrm{As}, \mathrm{Fe}, \mathrm{Cr}, \mathrm{Ni}, \mathrm{Zn}, \mathrm{Pb}$ ve $\mathrm{Cu}$ birikim miktarlarının tespiti için her dokudan 3-5 gr alınmıştır. Doku örnekleri ısıya dayanıklı küçük cam şişeler içerisine konup $105{ }^{\circ} \mathrm{C}$ 'de 24 saat ETÜV de bekletilerek kurutulmuş ve daha sonra 24 saat soğutulmaya bırakılmıştır. Her bir örnek toz haline getirilerek, hassas terazide $0.5 \mathrm{gr}$ olacak şekilde tartılarak teflon mikro dalga tüplerinin içine konulmuştur. $7 \mathrm{ml} \mathrm{HNO}_{3}$ ve $1 \mathrm{ml} \mathrm{H}_{2} \mathrm{O}_{2}$ ilave edilerek 24 saat için oda sıcaklığında bekletilmiştir. Alınan numuneler Vorteks'te 10 dakika çalkalanarak mineralize olması sağlanmıştır. Örnekler mikro dalga tüplerinin içine konularak 45 dakika $110^{\circ} \mathrm{C}^{\prime} \mathrm{de}$ 700 watt'da yakılmıştır. Örnekler çeker ocakta açılarak deiyonize su ile 200 ml'ye tamamlanmıştır. Teflon filtreden geçirilen örnekler analize hazır duruma getirilmiştir. Hazırlanan örneklerin ağır metal analizleri, ICP-MS (İndüktif Olarak Eşleştirilmiş Plazma - Kütle Spektrometresi) cihazı kullanılarak ölçülmüştür.

Sedimentlerin analizi Tekin-Özan ve Kır (2005)'ın yaptıkları çalışmaya göre yapılmıştır. Buna göre, ölçüm için mikrodalga çözünürleştirme tüplerine sediment örneklerinden 1'er gr yerleştirilerek, her bir tüpün üzerine de $5 \mathrm{ml} \mathrm{HNO}_{3}$ ve $1 \mathrm{ml} \mathrm{H} \mathrm{H}_{2}$ ilave edilmiştir. Tüpler Milestone marka Ethos Plus 2000 model mikrodalga fırına konularak çözünürleştirme işlemi yapılmıştır. Daha sonra tüpler fırından çıkarılarak oda sıcaklığında soğutulmuştur. Soğuyan tüplerdeki çözeltiler 25 ml'lik polipropilen balon jojelere aktarılmıştır ve saf su ile çözelti mikarı 25 ml'ye tamamlanmıştır. Örneklerin metal analizi Perkin Elmer marka 5300 DV model ICP-OES (İndaktif eşleşmiş plazma Optik Emisyon Spektrometresi) cihazında yapılmıştır. Su örneklerinde analizler doğrudan ICP-OES cihazında yapılmıştır.

\section{Istatistiksel analizler}

Sonuçların, minimum değeri, maksimum değeri, aritmetik ortalamaları ve standart sapmaları hesaplanmıştır. Su, sediment ve balık dokularının metal konsantrasyonları, suyun sıcaklık, $\mathrm{pH}$ ve çözünmüş oksijen değerleri ile ağır metal miktarları arasındaki ilişkiyi, balıkların ağırlıkları ve boyları ile dokularda biriken ağır metal miktarları arasındaki ilişkiyi ortaya koymak amacıyla, Pearson Testi ile Linear Regression Analizi yapılmıştır. Çalışmadaki bütün hesaplamalar için SPSS 17 programı kullanılmıştır.

\section{Bulgular ve Tartışma}

Bu çalışmada Erzincan ili sınırları içinde kalan Karasu Nehri'nin suyunda, sedimentinde ve nehirde yaşayan Capoeta umbla balıklarının solungaç, karaciğer ve kas dokularındaki metal ( $\mathrm{Al}, \mathrm{As}, \mathrm{Cr}, \mathrm{Cu}$, $\mathrm{Fe}, \mathrm{Mn}, \mathrm{Ni}, \mathrm{Pb}$ ve $\mathrm{Zn}$ ) konsantrasyonları belirlenmiş, suda ölçülen bazı fiziko-kimyasal parametrelerle sudaki ağır metal düzeyleri arasındaki ilişki tespit edilmiştir. Ayrıca, C. umbla dokularında tespit edilen metal miktarları ile balıkların boy ve ağırlıkları arasındaki ilişki belirlenmiştir.

Çalışma boyunca Karasu Nehri suyunun sıcaklığı, pH değeri ve çözünmüş oksijen miktarı ölçülmüş ve sonuçlar Çizelge 1'de verilmiştir. Çizelge $1^{\prime}$ e göre en yüksek sıcaklık değeri $14.6{ }^{\circ} \mathrm{C}$ iken en düşük sıcaklık $9.7^{\circ} \mathrm{C}$ ve ortalama sıcaklık değeri 11.7 ${ }^{\circ} \mathrm{C}$ olarak ölçülmüştür.

Karasu Nehri'nin suyunda yapılan ağır metal analizlerinin sonuçları Çizelge 2'de verilmiştir. Suda yapılan ağır metal analizleri sonucunda nehir suyunda en fazla As metalinin biriktiği tespit edilmiştir. Bunun yanında, Al, Fe, Pb ve $\mathrm{Zn}$ metalleri ise analiz limitlerinin altında kalmıştır. Suda metal birikimlerinin ortalama değerlerine göre birikim As $>\mathrm{Ni}>\mathrm{Cr}>\mathrm{Cu}>\mathrm{Mn}$ şeklinde olduğu tespit edilmiştir. Sudaki metal değerleri; As: 2.207-10.472; Cr: 0.0780.957; Cu: 0.060-0.428; Mn: 0.004-0.145; Ni: 1.231$9.585 \mathrm{ppb}$ arasında oldukları belirlenmiştir. 
Çizelge 1. Karasu Nehri'nin sıcaklık, pH ve çözünmüş oksijen değerlerinin maksimum, minimum, ortalama ve standart sapma değerleri.

$\begin{array}{lccc} & \text { Sıcaklık }\left({ }^{\circ} \mathbf{C}\right) & \text { pH } & \text { Çözünmüş oksijen }(\mathbf{m g} / \mathbf{l t}) \\ \text { Minimum } & 9.7 & 7.7 & 7.3 \\ \text { Maksimum } & 14.6 & 8.3 & 9.8 \\ \text { Ortalama } & 11.7 & 8.0 & 8.6 \\ \text { Standart Sapma } & 0.16 & 0.25 & 0.39\end{array}$

Çizelge 2. Karasu Nehri'nin suyunda ölçülen metal konsantrasyonlarının minimum değerleri, maksimum değerleri, ortalama değerleri ( $\mathrm{ppb}$ ) ve standart sapmaları.

\begin{tabular}{lccccccccc}
\hline & Al & As & Cr & Cu & Fe & Mn & Ni & Pb & Zn \\
\hline Minimum & ALA* & 2.207 & 0.078 & 0.060 & ALA* & 0.004 & 1.231 & ALA $^{*}$ & ALA* \\
Maksimum & & 10.472 & 0.957 & 0.428 & & 0.145 & 9.585 & & \\
Ortalama & & 6.719 & 0.644 & 0.131 & & 0.045 & 6.509 & & \\
Standart Sapma & & 1.640 & 0.077 & 0.038 & & 0.013 & 0.974 & & \\
\hline
\end{tabular}

*ALA: Analiz limitinin altında.

Çizelge 3. Karasu Nehri'nin suyunda ölçülen bazı fiziko-kimyasal parametreler ve metallerin pearson testine göre belirlenen değerleri.

\begin{tabular}{|c|c|c|c|c|c|c|c|c|}
\hline & Sıcaklık & $\mathrm{pH}$ & $\begin{array}{l}\text { Çözünmüş } \\
\text { oksijen }\end{array}$ & As & $\mathrm{Cr}$ & $\mathrm{Cu}$ & $M n$ & $\mathbf{N i}$ \\
\hline Sıcaklık & 1 & -0.024 & 0.144 & 0.019 & $0.683^{*}$ & -0.638 & 0.469 & 0.057 \\
\hline $\mathrm{pH}$ & & 1 & 0.556 & -0.471 & 0.322 & -0.117 & 0.231 & -0.472 \\
\hline $\begin{array}{l}\text { Çözünmüş } \\
\text { Oksijen }\end{array}$ & & & 1 & -0.222 & -0.066 & 0.288 & -0.099 & -0.448 \\
\hline As & & & & 1 & -0.057 & 0.232 & 0.065 & $0.698 *$ \\
\hline $\mathrm{Cr}$ & & & & & 1 & $-0.830 * *$ & 0.330 & 0.044 \\
\hline $\mathrm{Cu}$ & & & & & & 1 & -0.198 & 0.223 \\
\hline $\mathrm{Mn}$ & & & & & & & 1 & 0.351 \\
\hline $\mathrm{Ni}$ & & & & & & & & 1 \\
\hline
\end{tabular}

*0.05 düzeyinde önemli, ${ }^{* *} 0.01$ düzeyinde önemli.

Çizelge 4. Karasu Nehri sedimentinde ölçülen metal konsantrasyonlarının minimum değerleri, maksimum değerleri, ortalama değerleri (mg/ $\mathrm{kg}$ ) ve standart sapmaları.

\begin{tabular}{cccccccccc}
\hline & Al & As & Cr & Cu & Fe & Mn & Ni & Pb & Zn \\
\hline Minimum & ALA $^{*}$ & 0.037 & 128.360 & ALA $^{*}$ & 912.721 & ALA* & 127.112 & 0.359 & 3.226 \\
Maksimum & & 0.151 & 889.802 & & 11246.596 & & 980.126 & 5.647 & 62.320 \\
Ortalama & & 0.062 & 398.648 & & 6267.335 & & 411.600 & 2.994 & 35.023 \\
Standart Sapma & & 0.004 & 13.004 & & 26.697 & & 16.237 & 0.127 & 1.915 \\
\hline
\end{tabular}

*ALA: Analiz limitinin altında.

Karasu Nehri'nden alınan sediment örneklerinde belirlenen ağır metal miktarları Çizelge 4'de verilmiştir. Sedimentte yapılan metal analizleri sonucunda nehir suyunda en fazla Fe metalinin biriktiği, en az birikiminde As metalinde olduğu tespit edilmiştir. Bunun yanında, $\mathrm{Al}, \mathrm{Cu}$ ve $\mathrm{Mn}$ metalleri ise analiz limitlerinin altında kalmıştır.Ortalama değerlerine göre sedimentte metal birikimi; $\mathrm{Fe}>\mathrm{Ni}>\mathrm{Cr}>\mathrm{Zn}>\mathrm{Pb}>\mathrm{As}$ şeklinde olduğu belirlenmiştir. Sedimentte bulunan minimum ve maksimum metal değerleri; As: 0.037-0.151; Cr: 128.360-899.802; Fe: 912.721-11246.596; Ni: 127.112-980.126; $\mathrm{Pb}$ : 0.359-5.647; $\mathrm{Zn}: 3.226-$ $62.320 \mathrm{mg} / \mathrm{kg}$ arasında oldukları belirlenmiştir.
Araştırma kapsamında C. umbla balıkları, bölgede avcılık yapan balıkçıların yardımıyla temin edilmiştir. Çalışmada; $34.4 \pm 2.42 \mathrm{~cm}$ boyunda, $480 \pm 3.81$ gr ağırlığında toplam 22 tane Capoeta umbla kullanılmıştır. Karasu Nehri'nden yakalanan C. umbla, solungaç, karaciğer ve kas dokularında belirlenen ağır metal ( $\mathrm{Al}, \mathrm{As}, \mathrm{Cr}, \mathrm{Cu}, \mathrm{Fe}, \mathrm{Mn}, \mathrm{Ni}, \mathrm{Pb}$ ve $\mathrm{Zn}$ ) konsantrasyonlarının miktarları sırasıyla Çizelge 5'de verilmiştir.

Çizelge 5'e göre $C$. umbla kas, karaciğer ve solungaç dokularında en fazla Fe metalinin biriktiği, en az birikiminde $\mathrm{Pb}$ metalinde olduğu tespit edilmiştir. Ortalama değerlere göre metal birikimi kas dokusunda, $\mathrm{Fe}>\mathrm{Al}>\mathrm{Zn}>\mathrm{Mn}>\mathrm{Ni}>\mathrm{Cr}>\mathrm{Cu}>\mathrm{As}>\mathrm{Pb}$; karaciğer

dokusunda 
$\mathrm{Fe}>\mathrm{Al}>\mathrm{Zn}>\mathrm{Cu}>\mathrm{Mn}>\mathrm{Cr}>\mathrm{Ni}>\mathrm{As}>\mathrm{Pb} ; \quad$ solungaç dokusunda $\mathrm{Fe}>\mathrm{Zn}>\mathrm{Al}>\mathrm{Mn}>\mathrm{Ni}>\mathrm{Cr}>\mathrm{As}>\mathrm{Cu}>\mathrm{Pb}$ şeklinde olduğu belirlenmiştir.

C. umbla kas, karaciğer ve solungaç dokularında tespit edilen metallerin konsantrasyonları ile balıkların boy ve ağırlıkları arasındaki ilişki linear regresyon analizi ile belirlenmiştir (Çizelge 6 ve 7). Çizelge $6^{\prime} \mathrm{da}$ görüldüğü gibi balık kas dokusunda, $\mathrm{Al}, \mathrm{Cr}, \mathrm{Fe}, \mathrm{Mn}$, $\mathrm{Ni}$ ve $\mathrm{Pb}$ metalleri ile balık boyu arasında pozitif doğrusal bir ilişki varken, As, Cu ve $\mathrm{Zn}$ metalleri ile balık boyu arasında negatif doğrusal bir ilişki vardır. Karaciğer dokusunda, $\mathrm{Cr}$ ve $\mathrm{Mn}$ metalleri ile balık boyu arasında pozitif doğrusal bir ilişki varken, $\mathrm{Al}$, $\mathrm{As}, \mathrm{Cu}, \mathrm{Fe}, \mathrm{Ni}, \mathrm{Pb}$ ve $\mathrm{Zn}$ metalleri ile balık boyu arasında negatif doğrusal bir ilişki vardır. Solungaç dokusunda, $\mathrm{As}, \mathrm{Cr}, \mathrm{Mn}$, Ni ve $\mathrm{Pb}$ metalleri ile balık boyu arasında pozitif doğrusal bir ilişki varken, Al, $\mathrm{Cu}, \mathrm{Fe}$ ve $\mathrm{Zn}$ metalleri ile balık boyu arasında negatif doğrusal bir ilişki vardır. Kas dokuda, korelasyon katsayılarının istatistiki olarak anlamlı olup olmadığına bakıldığında As metalinin konsantrasyonu ile balıkların boy uzunlukları arasındaki ilişkinin istatistiki olarak anlamlı $(P<0.05)$ olduğu sonucu bulunmuştur. Bununla beraber, Regresyon denkleminde ise $\mathrm{Cr}$ ve $\mathrm{Mn}$ metalleri ile balıkların boy uzunlukları arasındaki ilişkinin istatistiki olarak anlamlı $(P<0.05)$ olduğu görülmektdir. Karaciğer dokusunda, $\mathrm{Cu}$ metalinin konsantrasyonu ile balıkların boy uzunluğu arasında istatistiki olarak $(P<0.05)$ zayıf negatif anlamlı bir korelasyon belirlenmiştir. Regresyon denkleminde ise hiçbir ağır metal konsantrasyonunun katsayıları istatistiki olarak anlamlı bulunmamıştır. Solungaç dokusunda, korelasyon katsayılarının istatistiki olarak anlamlı olup olmadığına bakıldığında Al ve Fe metallerinin konsantrasyonu ile balıkların boy uzunlukları arasındaki ilişkinin istatistiki olarak anlamlı $(P<0.05)$ olduğu sonucu bulunmuştur. Regresyon denkleminde ise Ni metali ile balıkların boy uzunlukları arasındaki ilişkinin istatistiki olarak anlamlı $(P<0.05)$ olduğu görülmektedir.

Çizelge 7'de görüldüğü gibi kas dokusunda, $\mathrm{Al}, \mathrm{Cr}$ ve $\mathrm{Pb}$ metalleri ile balık ağırlığı arasında pozitif doğrusal bir ilişki varken, $\mathrm{As}, \mathrm{Cu}, \mathrm{Fe}, \mathrm{Mn}, \mathrm{Ni}$ ve $\mathrm{Zn}$ metalleri ile balık ağırlığı arasında negatif doğrusal bir ilişki vardır. Karaciğer dokusunda, $\mathrm{Cr}, \mathrm{Mn}$ ve $\mathrm{Pb}$ metalleri ile balık ağırlığı arasında pozitif doğrusal bir ilişki varken, $\mathrm{Al}, \mathrm{As}, \mathrm{Cu}, \mathrm{Fe}, \mathrm{Ni}$ ve $\mathrm{Zn}$ metalleri ile balık ağırlığı arasında negatif doğrusal bir ilişki vardır. Solungaç dokusunda, $\mathrm{As}, \mathrm{Cr}, \mathrm{Mn}, \mathrm{Ni}$ ve $\mathrm{Pb}$ metalleri ile balık ağırlığı arasında pozitif doğrusal bir ilişki varken, $\mathrm{Al}, \mathrm{Cu}$, Fe ve $\mathrm{Zn}$ metalleri ile balık ağırlığı arasında negatif doğrusal bir ilişki vardır. Kas dokusunda, As metalinin konsantrasyonu ile ağırlık arasında istatistiki olarak anlamlı $(\mathrm{P}<0.05)$ ve zayıf bir korelasyon belirlenmiştir. Yapılan regresyon analizinde $\mathrm{Mn}$ metalinin konsantrasyonunun katsayısı istatistiki olarak anlamlı $(P<0.05)$ bulunmuştur. Karaciğer dokusunda metal konsantrasyonu ve balık ağırlığı arasındaki korelasyonlar istatistiki olarak anlamlı $(P<0.05)$ bulunmamıştır. Metal konsantrasyonlarının regresyon analizinde bulunan katsayıları da istatistiki olarak önemli çıkmamıştır. Solungaç dokusunda, Al ve Fe metallerinin konsantrasyonları ile balıkların ağırlıkları arasındaki korelasyon istatistiki olarak anlamlı $(P<0.05)$ bulunmuştur. Regresyon analizinde ise, $\mathrm{Mn}$ metalinin konsantrasyonunun katsayısı istatistiki olarak anlamlı $(P<0.05)$ olduğu tespit edilmiştir.

Su, tüm canlıların hayatını devam ettirebilmesi için şarttır. Özellikle insanlar için sağlıklı kalmanın yanında, temizlik ve tarım gibi faaliyetlerde yoğun şekilde kullanılan ve yerine başka bir maddenin kullanılamadığı hayati ve vazgeçilmez bir maddedir. Nüfusun artmasıyla beraber kentleşme ve sanayileşme artmış ve bunun sonucu olarakta sanayi ve kentsel atıklar kanalizasyon yoluyla akarsu, baraj ve göllere boşaltılılarak kullanılabilir su kaynakları kirletilmektedir (Çalışkan, 2005). Günümüzde su kaynaklarının yoğun şekilde kirliliği canlı yaşamını tehditeder duruma gelmiştir. Çevre koşullarına dikkate alındığında özellikle metaller ekosisteme en fazla zararı veren kirleticillerdir. Çünkü; bulundukları ortamda, fiziksel yollarla ayrışamadıkları için uzun süre varlığını devam ettirirler. Bunun sonucu olarakta metallerin yol açtığı su kirliliği ve sucul organizmalara olan etkileri ile ilgili çalışmalar giderek artmakta ve ilgi görmektedir (Machado ve ark., 1999; Storelli ve ark., 2005; Mol ve ark., 2010; Kırıcı ve ark., 2013a; Atamanalp ve ark., 2016; Adebayo, 2017; Ahmed ve ark., 2017; Kırıcı ve ark., 2017a).

Bu çalışmada, Mart 2018 - Mayıs 2018 tarihleri arasında Erzincan ili sınırları içinde kalan Karasu Nehri'nin suyunda, sedimentinde ve nehirde yaşayan Capoeta umbla balıklarının solungaç, karaciğer ve kas dokularındaki metal (Al, As, $\mathrm{Cr}, \mathrm{Cu}$, $\mathrm{Fe}, \mathrm{Mn}, \mathrm{Ni}, \mathrm{Pb}$ ve $\mathrm{Zn}$ ) konsantrasyonları incelenmiştir.

Çalışmada, öncelikle nehir suyunun sıcaklığı, pH değeri ve çözünmüş oksijen miktarı ölçülmüştür. Ölçüm sonuçları ülkemizde göl ve akarsularda yapılan diğer çalışmaların sonuçları ile benzerlik göstermektedir (Gülcü-Gür, 2014; Kaptan ve TekinÖzan, 2014; Özan, 2016).

Pearson Testi kullanılarak, suda ölçülen sıcaklık, pH ve çözünmüş oksijen ile suda tespit edilen metallerin düzeyleri arasındaki ilişkiler belirlenmiş ve Çizelge 3'de verilmiştir. Buna göre, sıcaklık ile ph arasında negatif, çözünmüş oksijen arasında pozitif bir ilişki vardır. 
Çizelge 5. Capoeta umbla'ya ait kas, karaciğer ve solungaç dokularında tespit edilen bazı metallerin maksimum, minimum, ortalama değerleri (mg/kg) ve standart sapmaları.

\begin{tabular}{|c|c|c|c|c|c|c|c|c|c|c|c|c|}
\hline \multirow{2}{*}{$\begin{array}{l}\text { Doku } \\
\text { Metal }\end{array}$} & \multicolumn{4}{|c|}{ Kas } & \multicolumn{4}{|c|}{ Karaciğer } & \multicolumn{4}{|c|}{ Solungaç } \\
\hline & Min. & Maks. & Ort. & Std. Sap. & Min. & Maks. & Ort. & Std. Sap. & Min. & Maks. & Ort. & Std. Sap. \\
\hline $\mathrm{Al}$ & 2.704 & 286.897 & 94.800 & 7.672 & 59.982 & 392.947 & 134.600 & 1.720 & 9.197 & 135.577 & 28.954 & 0.933 \\
\hline As & 0.029 & 1.019 & 0.483 & 0.029 & 0.021 & 5.438 & 1.877 & 0.019 & 0.090 & 2.105 & 0.849 & 0.041 \\
\hline $\mathrm{Cr}$ & 0.013 & 7.028 & 2.012 & 0.168 & 0.839 & 7.114 & 3.410 & 0.064 & 1.535 & 7.420 & 3.014 & 0.072 \\
\hline $\mathrm{Cu}$ & 0.166 & 3.632 & 0.711 & 0.108 & 6.706 & 203.962 & 61.243 & 1.197 & 0.091 & 1.651 & 0.657 & 0.010 \\
\hline $\mathrm{Fe}$ & 2.323 & 502.321 & 172.556 & 11.114 & 55.595 & 405.377 & 267.734 & 3.203 & 10.715 & 291.161 & 100.938 & 2.304 \\
\hline $\mathrm{Mn}$ & 0.406 & 29.542 & 10.969 & 2.533 & 1.146 & 11.956 & 6.766 & 0.152 & 9.034 & 58.574 & 21.420 & 0.389 \\
\hline $\mathrm{Ni}$ & 0.092 & 5.688 & 2.890 & 0.447 & 0.509 & 3.388 & 2.002 & 0.147 & 0.753 & 8.406 & 3.532 & 0.209 \\
\hline $\mathrm{Pb}$ & 0.011 & 0.458 & 0.172 & 0.005 & 0.019 & 0.551 & 0.208 & 0.008 & 0.083 & 0.200 & 0.127 & 0.073 \\
\hline $\mathrm{Zn}$ & 0.894 & 63.262 & 24.066 & 2.310 & 17.581 & 154.038 & 61.460 & 1.238 & 33.969 & 161.236 & 81.262 & 1.034 \\
\hline
\end{tabular}

Çizelge 6. Capoeta umbla'nın boyu ve ağır metal konsantrasyonu arasındaki ilişkiler.

\begin{tabular}{|c|c|c|c|c|c|c|c|c|c|c|}
\hline 흥 & & Al & As & $\mathrm{Cr}$ & $\mathrm{Cu}$ & $\mathrm{Fe}$ & $M n$ & $\mathbf{N i}$ & $\mathbf{P b}$ & $\mathrm{Zn}$ \\
\hline \multirow{3}{*}{$\begin{array}{l}\mathscr{n} \\
\stackrel{\widetilde{\pi}}{ }\end{array}$} & Denklem & $\begin{array}{c}{ }^{a} X=37.569+1.2 \\
3 Y\end{array}$ & $\begin{array}{c}X=37.569- \\
0.580 Y\end{array}$ & $X=37.5+0.01 Y$ & $\begin{array}{c}X=37.569 \\
-0.507 Y\end{array}$ & $\begin{array}{c}X=37.569+3.13 \\
7 Y\end{array}$ & $X=37.569+0.00 Y$ & $X=37.569+0.00 Y$ & $\begin{array}{c}X=37.569+0.25 \\
8 Y\end{array}$ & $\begin{array}{c}X=37.569 \\
-0.120 Y\end{array}$ \\
\hline & $R$ Değeri & 0.328 & $-0.510 *$ & 0.262 & 0.096 & -0.073 & -0.377 & -0.071 & -0.084 & -0.260 \\
\hline & $P$ Değeri & 0.226 & 0.109 & $0.014^{*}$ & 0.158 & 0.158 & $0.015^{*}$ & 0.259 & 0.238 & 0.546 \\
\hline \multirow{3}{*}{ 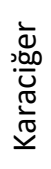 } & Denklem & $\begin{array}{c}X=36.387- \\
0.061 Y\end{array}$ & $\begin{array}{c}X=36.387- \\
0.192 Y\end{array}$ & $\begin{array}{c}X=36.387+0.15 \\
9 Y\end{array}$ & $\begin{array}{c}X=36.387 \\
-0.365 Y\end{array}$ & $\begin{array}{c}X=36.387- \\
0.217 \mathrm{Y}\end{array}$ & $\begin{array}{c}X=36.387+0.47 \\
1 Y\end{array}$ & $\begin{array}{c}X=36.387- \\
0.047 Y\end{array}$ & $\begin{array}{c}X=36.387- \\
0.043 Y\end{array}$ & $\begin{array}{c}X=36.387 \\
-0.489 Y\end{array}$ \\
\hline & $R$ Değeri & -0.178 & -0.342 & -0.099 & $-0.436^{*}$ & -0.091 & 0.062 & -0.238 & -0.004 & -0.315 \\
\hline & $P$ Değeri & 0.879 & 0.687 & 0.786 & 0.444 & 0.617 & 0.348 & 0.905 & 0.919 & 0.425 \\
\hline \multirow{4}{*}{ 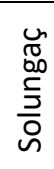 } & Denklem & $X=30.523-$ & $X=30.523+0.090$ & $X=30.523+0.34$ & $X=30.523$ & $x=30.523-$ & $X=30.523+0.09$ & $X=30.523+0.65$ & $X=30.523+0.32$ & $X=30.523$ \\
\hline & Denkiem & $0.455 Y$ & $\mathrm{Y}$ & OY & $-0.091 Y$ & $0.451 Y$ & $3 Y$ & $3 Y$ & $4 \mathrm{Y}$ & $-0.220 Y$ \\
\hline & $R$ Değeri & $-0.608 *$ & 0.199 & 0.085 & 0.083 & $-0.601^{*}$ & -0.045 & 0.204 & 0.079 & -0.004 \\
\hline & $P$ Değeri & 0.163 & 0.774 & 0.291 & 0.838 & 0.251 & 0.726 & $0.050 *$ & 0.492 & 0.510 \\
\hline
\end{tabular}

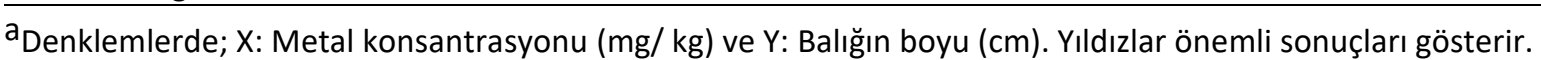

* 0.05 düzeyinde önemli, $P<0.05$. 
Çizelge 7. Capoeta umbla'nın ağırlı̆̆ı ve ağır metal konsantrasyonu arasındaki ilişkiler.

\begin{tabular}{|c|c|c|c|c|c|c|c|c|c|c|}
\hline 훙 & & Al & As & $\mathrm{Cr}$ & $\mathrm{Cu}$ & $\mathrm{Fe}$ & Mn & $\mathrm{Ni}$ & $\mathrm{Pb}$ & $\mathrm{Zn}$ \\
\hline \multirow{3}{*}{$\begin{array}{l}\mathscr{n} \\
\stackrel{\pi}{\square}\end{array}$} & Denklem & $\begin{array}{c}{ }^{a} X=571.642+0.3 \\
17 Y\end{array}$ & $\begin{array}{c}X=571.642- \\
0.557 Y\end{array}$ & $\begin{array}{c}X=571.642+0.69 \\
9 Y\end{array}$ & $\begin{array}{l}X=571.64 \\
2-0.402 Y\end{array}$ & $\begin{array}{l}X=571.64 \\
2-0.206 Y\end{array}$ & $\begin{array}{c}X=571.642- \\
0.683 \mathrm{Y}\end{array}$ & $\begin{array}{c}X=571.642- \\
0.234 Y\end{array}$ & $\begin{array}{c}X=571.642+0.30 \\
\text { OY }\end{array}$ & $\begin{array}{l}X=571.64 \\
2-0.130 Y\end{array}$ \\
\hline & $R$ Değeri & 0.253 & $-0.454^{*}$ & 0.257 & 0.146 & -0.052 & -0.408 & -0.063 & 0.001 & -0.231 \\
\hline & $P$ Değeri & 0.455 & 0.240 & 0.081 & 0.392 & 0.375 & $0.045^{*}$ & 0.566 & 0.314 & 0.635 \\
\hline \multirow{3}{*}{ 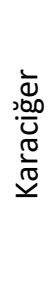 } & Denklem & $\begin{array}{c}X=535.726- \\
0.029 Y\end{array}$ & $\begin{array}{c}X=535.726- \\
0.235 Y\end{array}$ & $\begin{array}{c}X=535.726+0.14 \\
5 Y\end{array}$ & $\begin{array}{l}X=535.72 \\
6-0.263 Y\end{array}$ & $\begin{array}{l}X=535.72 \\
6-0.107 Y\end{array}$ & $\begin{array}{c}X=535.726+0.40 \\
2 Y\end{array}$ & $\begin{array}{c}X=535.726- \\
0.116 Y\end{array}$ & $\begin{array}{c}X=535.726+0.01 \\
2 Y\end{array}$ & $\begin{array}{r}X=535.72 \\
6-0.500 Y\end{array}$ \\
\hline & $R$ Değeri & 0.223 & -0.387 & -0.176 & -0.351 & 0.018 & 0.084 & -0.276 & 0.079 & -0.386 \\
\hline & $P$ Değeri & 0.942 & 0.624 & 0.805 & 0.577 & 0.805 & 0.419 & 0.772 & 0.978 & 0.416 \\
\hline \multirow{3}{*}{ 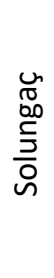 } & Denklem & $\begin{array}{c}X=335.615- \\
0.525 Y\end{array}$ & $\begin{array}{c}X=335.615+0.18 \\
8 Y\end{array}$ & $\begin{array}{c}X=335.615+0.29 \\
4 Y\end{array}$ & $\begin{array}{l}X=335.61 \\
5-0.009 Y\end{array}$ & $\begin{array}{l}X=335.61 \\
5-0.337 Y\end{array}$ & $\begin{array}{c}X=335.615+0.16 \\
1 Y\end{array}$ & $\begin{array}{c}X=335.615+0.70 \\
\text { OY }\end{array}$ & $\begin{array}{c}X=335.615+0.28 \\
2 Y\end{array}$ & $\begin{array}{l}X=335.61 \\
5-0.266 Y\end{array}$ \\
\hline & $R$ Değeri & $-0.615^{*}$ & 0.252 & 0.104 & 0.144 & $-0.546^{*}$ & -0.010 & 0.235 & -0.011 & -0.055 \\
\hline & $P$ Değeri & 0.101 & 0.529 & 0.330 & 0.983 & 0.353 & 0.523 & $0.032 *$ & 0.525 & 0.405 \\
\hline
\end{tabular}

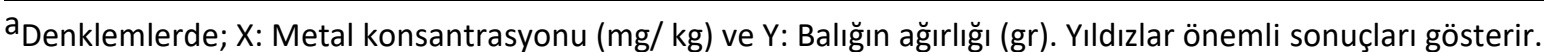

* 0.05 düzeyinde önemli, $P<0.05$. 
Yani sıcaklık artarken, pH değeri azalmakta, çözünmüş oksijen miktarı artmaktadır. pH ile çözünmüş oksijen miktarı arasında ise pozitif ilişki vardır, yani $\mathrm{pH}$ artarken çözünmüş oksijen miktarı da artmaktadır. Sıcaklık ve $\mathrm{Cu}$ arasında negatif bir ilişki varken, $\mathrm{As}, \mathrm{Cr}$, Mn ve Ni arasında pozitif bir ilişki vardır. $\mathrm{pH}$ ile $\mathrm{As}, \mathrm{Cu}$ ve $\mathrm{Ni}$ arasında negatif ilişki varken, $\mathrm{Cr}$ ve $\mathrm{Mn}$ arasında pozitif bir ilişki vardır. Çözünmüş oksijen ile $\mathrm{Cu}$ arasında pozitif bir ilişki varken, $\mathrm{As}, \mathrm{Cr}, \mathrm{Mn}$ ve $\mathrm{Ni}$ arasında negatif bir ilişki vardır. Ayrıca, sıcaklık ve $\mathrm{Cr}$ arasında $(\mathrm{P}<0.05)$, As ve $\mathrm{Ni}$ arasında $(<0.05)$ ve $\mathrm{Cr}$ ve $\mathrm{Cu}$ arasında $(\mathrm{P}<0.01)$ istatistiki açıdan önemli farklılıklar belirlenmiştir.

Çalışmada, yapılan metal analizleri sonucunda Karasu Nehri'nin suyunda en fazla As metalinin biriktiği bunu sırasıyla $\mathrm{Ni}, \mathrm{Cr}, \mathrm{Cu}, \mathrm{Mn}$ metallerinin izlediği tespit edilmiştir. Bunun yanında, $\mathrm{Al}, \mathrm{Fe}, \mathrm{Pb}$ ve $\mathrm{Zn}$ metalleri ise analiz limitlerinin altında kalmıştır. Dostbil (2010) Mogan Gölü’nde yaptığı çalışmada göl suyunda Al, As, Cd, $\mathrm{Cu}, \mathrm{Fe}, \mathrm{Hg}, \mathrm{Ni}, \mathrm{Pb}, \mathrm{Zn}$ metallerinin düzeylerini incelemiş ve çalışma sonucunda en yüksek $\mathrm{Pb}$ metalinin bulunduğunu onu sırasıyla $\mathrm{Al}, \mathrm{Fe}, \mathrm{As}, \mathrm{Ni}$, $\mathrm{Hg}, \mathrm{Cu}, \mathrm{Zn}, \mathrm{Cd}$ metallerinin takip ettiğini tespit etmiştir. Benzer şekilde Özan (2016), Isparta Deresi'nde yaptığı çalışmada dere suyunda en yüksek Fe metalinin olduğunu bunu sırasıyla $\mathrm{Pb}, \mathrm{Cd}$, $\mathrm{Zn}, \mathrm{Mn}, \mathrm{Cu}, \mathrm{Cr}$ metallerinin takip ettiğini belirlemiştir. Farklı su kaynaklarında yapılan bu çalışmalarda metallerin birikim düzeylerinin farklı çıkmasının en önemli nedeni su kaynaklarının bulunduğu bölgedeki jeolojik kaynaklarının farklılı̆ınından kaynaklanabilir (Kaptan ve TekinÖzan, 2014). Bunun yanında tespit edilen ağır metallerin ise, Dünya Sağlık Örgütü (WHO), Türk Standartları Enstitüsü (TSE), Tarım ve Orman Bakanlığı ve Amerika Birleşik Devletleri Çevre Koruma Ajansı (USEPA)'nın belirlediği suda kabul edilebilir ağır metal miktarları ile kıyaslandığında, tüm metallerin kabul edilebilir değerlerin altında olduğu belirlenmiştir.

Sedimentte yapılan metal analizleri sonucunda nehir suyunda en fazla Fe metalinin biriktiği, en az birikiminde As metalinde olduğu tespit edilmiştir. Sırasıyla sedimentte birikim değerleri; $\mathrm{Fe}>\mathrm{Ni}>\mathrm{Cr}>\mathrm{Zn}>\mathrm{Pb}>\mathrm{As}$ şeklinde olduğu belirlenmiştir. Bunun yanında, $\mathrm{Al}, \mathrm{Cu}$ ve $\mathrm{Mn}$ metalleri ise analiz limitlerinin altında kalmıştır. $\mathrm{Bu}$ çalışma ile benzer sonuçların elde edildiği başka bir çalışma da, Öztürk ve ark. (2009) Avşar Baraj Gölü'nde sedimentte biriken ağır metal düzeylerinin $\mathrm{Fe}>\mathrm{Ni}>\mathrm{Cu}>\mathrm{Cr}>\mathrm{Pb}>\mathrm{Cd}$ şeklinde olduğunu tespit etmiştir. Bununla beraber, Erçişli (2016) Kars Çayı'nda yaptığı çalışmada sedimentte metal düzeylerini $\mathrm{Pb}>\mathrm{Fe}>\mathrm{Cd}>\mathrm{Cr}>\mathrm{Mn}>\mathrm{Zn}>\mathrm{Cu}$ şeklinde belirlemiştir. Yapılan çalışmalarda genel olarak sedimentte en fazla varlığı görülen metal Fe metalidir. Usero ve ark. (2003) Fe metalinin göl, akarsu ve denizlerin sedimentinde diğer metallere göre fazla miktarda bulunmasının nedenini yerküre kabuğunda en fazla bulunan metalin Fe olmasıyla açıklamışlardır. Ayrıca, Karasu Nehri'nden alınan sediment örneklerinde tespit edilen ağır metaller ise Amerika Ulusal Okyanus ve Atmosfer Dairesi (NOOA) verilerine göre $\mathrm{Cr}$, $\mathrm{Fe}$ ve $\mathrm{Ni}$ kabul edilebilir değerlerin üstünde olduğu tespit edilmiştir.

C. umbla solungaç, karaciğer ve kas dokularında analizi yapılan $\mathrm{Al}, \mathrm{As}, \mathrm{Cr}, \mathrm{Cu}, \mathrm{Fe}, \mathrm{Mn}, \mathrm{Ni}$, $\mathrm{Pb}$ ve $\mathrm{Zn}$ metalleri tüm dokularda tespit edilmiştir. Karaciğer, metallerin en fazla biriktiği organ olup onu sırasıyla solungaç ve kas dokusunun izlediği belirlenmiştir. Balıklarda kas dokusu genel olarak balık dokuları içinde metal bağlanmasının en düşük olduğu dokudur. Kas dokusu, besin yoluyla metalin insanlara taşınmasında etkin rol aldığı için insan sağlığı açısından çok önemli bir dokudur. Bu yüzden balıkların kas dokusunda metal birikiminin az olması gıda güvenliği bakımından önemlidir. Balıklarda metal birikimi ile ilgili yapılan çalışmalarda genellikle en fazla metal birkimi karaciğer ve solungaç gibi spesifik dokularda olduğu, en az birikimin ise kas dokusunda olduğu belirtilmiştir (Tekin-Özan ve Kır, 2008; Alhas ve ark., 2009; Mol ve ark., 2010; Kır ve Tumantozlu, 2012; Kırıcı ve ark., 2013b). Başlıca solungaç, ağız ve deri yoluyla alınan metaller taşıyıcı proteinler ile beraber kan yoluyla dokulara ulaşmakta ve bu dokularda metal bağlayıcılar ile bağlanarak yüksek konsantrasyonlara ulaşabilmektedir. Ayrıca metallerin dokularda yüksek konsantrasyonlarda birikiminin yanında kan parametrelerini, enzim aktivitelerini (Kırıcı ve ark., 2016; Kırıcı ve ark., 2017b), büyüme ve gelişmeyi etkilediği belirtilmiştir (Sönmez ve ark., 2016).

C. umbla kas, karaciğer ve solungaç dokularında en fazla Fe metalinin biriktiği, en az birikiminde $\mathrm{Pb}$ metalinde olduğu tespit edilmiştir. Ortalama değerlere göre metal birikimi kas dokusunda, $\quad \mathrm{Fe}>\mathrm{Al}>\mathrm{Zn}>\mathrm{Mn}>\mathrm{Ni}>\mathrm{Cr}>\mathrm{Cu}>\mathrm{As}>\mathrm{Pb}$; karaciğer dokusunda $\mathrm{Fe}>\mathrm{Al}>\mathrm{Zn}>\mathrm{Cu}>\mathrm{Mn}>\mathrm{Cr}>\mathrm{Ni}>\mathrm{As}>\mathrm{Pb}$; solungaç dokusunda $\quad \mathrm{Fe}>\mathrm{Zn}>\mathrm{Al}>\mathrm{Mn}>\mathrm{Ni}>\mathrm{Cr}>\mathrm{As}>\mathrm{Cu}>\mathrm{Pb}$ şeklinde olduğu belirlenmiştir. Bu çalışmaya paralel olarak, Öztürk ve ark. (2009) Avşar Baraj Gölü'nde yaptıkları çalışmada Sazan kas, karaciğer ve solungaç dokularında metal birikim konsantrasyonlarını araştırmışlar ve çalışmada tüm dokularda en yüksek birikim Fe metalinde olurken en düşük birikim $\mathrm{Cd}$ metalinde olmuştur. Dokulardaki metal birikiminin sıralamasını kasta; $\mathrm{Fe}>\mathrm{Cu}>\mathrm{Pb}>\mathrm{Ni}>\mathrm{Cr}>\mathrm{Cd}$, solungaç ve karaciğerde; $\mathrm{Fe}>\mathrm{Cu}>\mathrm{Ni}>\mathrm{Pb}>\mathrm{Cr}>\mathrm{Cd}$ şeklinde tespit etmişlerdir.

C. umbla kas, karaciğer ve solungaç dokularında belirlenen ağır metal miktarları Dünya Sağlık Örgütü (WHO), Tarım ve Orman Bakanlığı ve 
Amerika Birleşik Devletleri Çevre Koruma Ajansı (USEPA)'nin belirlediği değerlerle kıyaslanmıştır. Bunun sonucunda, kas dokusunda $\mathrm{Mn}$ miktarı WHO'nun ve $\mathrm{Pb}$ miktarı WHO ve Tarım ve Orman Bakanlığı'nın; Karaciğer dokusunda As ve Zn miktarları Tarım ve Orman Bakanlığı'nın, Mn miktarı WHO'nun, Ni miktarı WHO ve Tarım ve Orman Bakanlığı'nın ve $\mathrm{Cu}$ miktarı WHO'nun, Tarım ve Orman Bakanlığı ve USEPA'nın; Solungaç dokusunda ise, Mn miktarı WHO'nun, Ni miktarı WHO ve Tarım ve Orman Bakanlığı ve $\mathrm{Zn}$ miktarı Tarım ve Orman Bakanlığı'nın belirlediği balık dokularında kabul edilebilir değerlerin üstünde çıkmıştır.

\section{Sonuç ve Öneriler}

Çalışma sonucunda Karasu Nehri'nin su, sediment ve balık dokularında tespit edilen metallerin birikimi ulusal ve uluslararası kurumların belirlediği kabuledilebilir değerler ile kıyaslanmıştır. Kıyaslama sonucunda nehrin suyunda herhangi bir tehlike olmadığı tespit edildi. Bunula beraber sediment ve balık dokularında ise bazı metallerin kabuledilebilir değerlerin üzerinde olduğu belirlenmiştir. Karasu Nehri üzerinde tarım alanaları bulunmaktadır. Özellikle tarımsal ilaçları ve gübreler bol miktarda metal içermektedir. Bu metaller özellikle yağmurlar ve hava yoluyla su kaynaklarına ulaşmaktadır. Ayrıca, nehrin çevresinde bulunan yerleşim yerlerinin de kanalizasyon ve evsel atıkları nehre karışmaktadır. Özellikle nehir çevresinde yaşayan halkın ve bu bölgedeki yetkililerinin bu konularda bilinçlendirilmesi, gübrelerin içerikleri ve evsel atıkların arıtılması ile ilgili bilgilendirilmeleri gerekmektedir.

Teşekkür: Bu çalışma Erzincan Binali Yıldırım Üniversitesi BAP koordinasyon birimi tarafından desteklenmiştir. Proje Numarası : FHD-2017-514

\section{Kaynaklar}

Adebayo, I.A. 2017. Determination of heavy metals in water, fish and sediment from Ureje Water Reservoir. Oceanography and Fisheries Open Access Journal, 4(1): 555-628.

Ahmed, Q., Bat, L. ve Ali, Q.M. 2017. Bioaccumulation of nine heavy metals in some tissues of Anodontostoma chacunda (Hamilton, 1822) in the Arabian Sea coasts of Pakistan. Natural and Engineering Sciences, 2(3): 79-92.

Alhas, E., Oymak, S.A. ve Karadede-Akın, H. 2009. Heavy metal concentrations in two barbus, Barbus xanthopterus and Barbus rajanorum mystaceus from Atatürk Dam Lake, Turkey.
Environmental Monitoring and Assessment, 148: $11-18$

Atamanalp, M., Kırıcı, M., Kırıcı, M. ve Beydemir, Ş. 2016. Investigation of in vitro effects of some metal ions on glucose 6-phosphate dehydrogenase which purified from freshwater fish Capoeta umbla kidney. 2nd International Congress on Applied Ichthyology and Aquatic Environment, 10-12 November, Messolonghi, Greece, pp. 39-43.

Bryan, G.W. 1976. Some aspects of heavy metal tolerance in aquatic organims. "Alınmıştır: Effects of Pollutants on Aquatic Organisms." (ed) Lockwood, A.P.M., Cambridge University Press, London, 7-34.

Çalışkan, E. 2005. Asi Nehri'nde Su, Sediment ve Karabalık (Clarias gariepinu Burchell, 1822)'ta Ağır Metal Birikiminin Araştırılması. Mustafa Kemal Üniversitesi, Fen Bilimleri Enstitüsü, Yüksek Lisans Tezi, Hatay.

Dostbil, M. 2010. Mogan Gölünde Su ve Sedimentte Ağır Metal Düzeylerinin Tespiti; Sazan (Cyprinus carpio) ve Kadife (Tinca tinca) Balık Dokuları Üzerine Etkilerinin İncelenmesi. Gazi Üniversitesi, Fen Bilimleri Enstitüsü, Çevre Bilimleri Anabilim Dalı, Yüksek Lisans Tezi, Ankara.

Egemen, Ö. 1999. Çevre ve Su Kirliliği. Ege Üniversitesi Su Ürünleri Fakültesi Yayınları, No: 42. İzmir, $101 \mathrm{~s}$.

Ercişli, B. 2016. Kars Çayı́nın Suyunda, Sedimentinde ve Bazı Sucul Organizmalarda İz Elementlerin Derişim Düzeylerinin Incelenmesi. Kafkas Üniversitesi, Fen Bilimleri Enstitüsü, Yüksek Lisan Tezi, Kars.

Gıda, Tarım ve Hayvancılık Bakanlığı (Tarım ve Orman Bakanlığı), 2002. Su Ürünleri Kanunu ve Su Ürünleri Yönetmeliği, Ankara, 63-78 s.

Göksu, M.Z.L. 2003. Su Kirliliği. Çukurova Üniversitesi Su Ürünleri Fakültesi Yayınları, No:7. Adana, $232 \mathrm{~s}$.

Gülcü-Gür, B. 2014. Işıklı Gölü'nün Suyunda, Sedimentinde ve Gölde Yaşayan Turna Balığı (Esox lucius L., 1758)'nın Bazı Doku ve Organlarındaki Ağır Metal Birikiminin Araştırılması. Süleyman Demirel Üniversitesi, Fen Bilimleri Enstitüsü, Yüksek Lisans Tezi, Isparta.

İsanç, A.T. 2010. Farklı Baraj Göllerindeki Balıkların Ağır Metal Birikimleri Üzerine Araştırmalar. Afyon Kocatepe Üniversitesi, Fen Bilimleri Enstitüsü, Yüksek Lisan Tezi, Afyon.

Kaptan, H. ve Tekin-Özan, S. 2014. Eğirdir Gölü'nün (Isparta) suyunda, sedimentinde ve gölde yaşayan sazan'ın (Cyprinus carpio L., 1758) bazı doku ve organlarındaki ağır metal düzeylerinin belirlenmesi. Süleyman Demirel 
Üniversitesi Fen Edebiyat Fakültesi Fen Dergisi, 9 (2): 44-60.

Kazancı, N. ve Oğuzku, D. 2003. Beyşehir Gölü'nün limnolojisi, çevre kalitesi, biyolojik çeşitliliği ve korunması. Türkiye İç Suları Araştırmaları Dizisi:VII., Ankara, 16-18 s.

Keskin, F. 2012. Köyceğiz Gölü Sedimentinde Ağır Metal Fraksiyonlarının İncelenmesi. Muğla Sıtkı Koçman Üniversitesi, Fen Bilimleri Enstitüsü, Yüksek Lisan Tezi, Muğla.

Kır, İ., Özan, S.T. ve Tuncay, T. 2007. Kovada Gölü'nün su ve sedimentindeki bazı ağır metallerin mevsimsel değişimi. Ege Üniversitesi Su Ürünleri Dergisi, 24 (1-2): 155-158.

Kır, İ. ve Tumantozlu, H. 2012. Karacaören-II baraj gölü'ndeki su, sediment ve sazan (Cyprinus carpio) örneklerinde bazı ağır metal birikiminin incelenmesi. Ekoloji, 21: 82, 6570.

Kırıcı, M., Taysi, M.R., Bengü, A.Ş. ve İspir, Ü. 2013a. Murat Nehri'nden yakalanan Capoeta capoeta umbla (Heckel, 1843)' da bazı metal düzeylerinin belirlenmesi. Iğdır Üniversitesi Fen Bilimleri Enstitüsü Dergisi, 3(1): 85-90.

Kırıcı, M., Taysi, M.R., Bengü, A.Ş. ve İspir, Ü. 2013b. Murat Nehri'nde yakalanan Capoeta trutta (Heckel, 1843)'nın kas dokusunda bazı metallerin birikim konsantrasyonlarının belirlenmesi. Erzincan Üniversitesi Fen Bilimleri Enstitüsü Dergisi, 6 (1): 115-124.

Kırıcı, M., Kırıcı, M., Beydemir, Ş. ve Atamanalp, M. 2016. Purification of carbonic anhydrase from Capoeta umbla (Heckel, 1843) gills and toxicological effects of some metals on enzyme activity. Turkish Journal of Fisheries and Aquatic Sciences, 16: 169-175.

Kırıcı, M., Atamanalp, M., Kırıcı, M. ve Beydemir, ş. 2017a. In vitro effects of some metal ions on glutathione reductase in the gills and liver of Capoeta trutta. Regulatory Mechanisms in Biosystems, 8(1): 66-70.

Kırıcı, M., Kırıcı, M., Beydemir, Ş. ve Bülbül, M. 2017b. Purification of glucose 6-phosphate dehydrogenase from gilthead sea bream (Sparus aurata) gill and liver tissues and inhibition effects of some metal ions on enzyme activity. Fresenius Environmental Bulletin, 26(12): 7074-7082.

Machado, L.M., Bebianno, M.J., Boski, T. ve Moura, D.M. 1999. Trace metals on the Algarve Coast, II: Bioaccumulation in mussels Mytilus galloprovincialis (Lamarck, 1819). Boletim do Instituto Oceanográfico, 15: 465-471.

Mol, S., Özden, Ö. ve Oymak, S.A. 2010. Trace metal contents in fish species from Atatürk Dam
Lake (Euphrates, Turkey). Turkish Journal of Fisheries and Aquatic Sciences, 10: 209-213.

Mutluay, H. ve Demirak, A. 1996. Su kimyası. Beta Basım Yayım Dağıtım, İstanbul, 83- $84 \mathrm{~s}$.

Özan, C. 2016. Isparta Deresi'nin Su ve Sedimentindeki Ağır Metal Birikiminin İncelenmesi. Yüksek Lisans Tezi, Süleyman Demirel Üniversitesi, Fen Bilimleri Enstitüsü, Isparta.

Öztürk, M., Özözen, G., Minareci, O. ve Minareci, E. 2009. Determination of Heavy Metals in Fish, Water and Sediments of Avsar Dam Lake in Turkey. Iranian Journal of Environmental Health Science and Engineering, 6 (2): 73-80.

Saler, S., Bulut, H., Birici, N., Tepe, R. ve Alpaslan, K. 2015. Karasu Nehri (Erzincan)'nin Zooplanktonu. Eğirdir Su Ürünleri Fakültesi Dergisi, 11(1): 10-16.

Salomans, W., Rooij N.M., Kerdijk, H. ve Bril. J. 1987. Sediments as a source for contaminants. Hydrobiologia. 149: 13-30.

Sawyer, C.N., Mccarty, P.L. ve Parkin, G.F. 1994. Chemistry for Environmental Engineering. McGraw Hill Book Co, Singapore, 768 p.

Şengül, F. ve Müezzinoğlu, A. 1993. Çevre Kimyası. Dokuz Eylül Üniversitesi Mühendislik Fakültesi Yayınları, No:228. İzmir, $243 \mathrm{~s}$.

Storelli, M.M., Storelli, A., D'ddabbo, R., Marano, C., Bruno, R. ve Marcotrigiano, G.O. 2005. Trace elements in loggerhead turtles (Caretta caretta) from the eastern Mediterranean Sea: Overview and evaluation. Environmental Pollution, 135: 163-170.

Tekin-Özan, S. ve Kır, İ. 2005. Comparative study on the accumulation of heavy metals in different organs of tench (Tinca tinca L., 1758) and plerocercoids of its endoparasite Ligula intestinalis. Parasitology Research, 97: 156-159.

Tekin-Özan, S. ve Kır, İ. 2008. Seasonal variations of heavy metals in some organs of Carp (Cyprinus carpio L., 1758) from Beyşehir Lake (Turkey). Environmental Monitoring and Assessment, 138: 201-206.

Türk Standartları Enstitüsü (TSE), 2005. Insani Tüketim Amacı Sular Hakkında Yönetmelik. Türk Standartları, Ankara.

United State Environmental Protection Agency (USEPA), 2005. National Recommended Water Quality Criteria Correction Washington, D.C.

Usero, J., Izquierdo, C., Morillo, J. ve Gracia, I. 2003. Heavy metals in fish ( Solea vulgaris, Anguilla anguilla and Liza aurata) from salt marshes on the Southern Atlantic Coast of Spain. Environmental International, 1069: 1-8. 
Uslu, H. 2007. Kars Çayı'ndan Avlanan Siraz (Capoeta capoeta capoeta Guldenstaedt, 1772) Balıklarında ve Ortam Sedimentinde Bazı Ağır Metallerin Derişim Düzeylerinin İncelenmesi. Kafkas Üniversitesi, Fen bilimleri Enstitüsü, Yüksek Lisan Tezi, Kars.
World Health Organization (WHO). 1993. Guidelines for Drinking-Water Quality, Recommendations, 1, 2nd Ed., Geneva.

Yarsan, E., Bilgili, A. ve Türel, í. 2000. Van Gölü'nden toplanan midye (Unio stevenianus Krynicki) örneklerindeki ağır metal düzeyleri. Turkish Journal of Veterinary and Animal Sciences, 24: 93-96. 